\title{
THE EFFECT OF USING DIRECT METHOD IN TEACHING SPEAKING SKILL AT THE SECOND YEAR OF SMK NEGERI 1 BENER MERIAH-ACEH
}

\author{
Umar Haliwanda ${ }^{1}$ \\ Syiah Kuala University, Banda Aceh, Indonesia \\ umar.wanda@mhs.unsyiah.ac.id
}

\begin{abstract}
This study aims at investigating at the use of Direct Method in the classroom, a few of English teacher applied many strategies and methods to increase students' speaking skill throughout describing and asking responses from the students, sometimes the teacher using group discussion, role play/simulation, picture story, and game, etc. . Besides, using interesting strategies or methods. But in reality, the students faced the problem, while the researcher using Direct Method in this study the students able to speak each other. Subsequently has improvement in speaking skill. The main focused in this study is to know the effect using Direct Method before and after being taught by using Direct Method. And also emphasizes the benefits of the Direct Method to teach how to communicate in the target language.
\end{abstract}

Keywords: Direct Method, Speaking skill, Teaching

\section{INTRODUCTION}

Language is a system that consists of the development, acquisition, maintenance, or use of complex systems of communication, particularly the human ability to do so; and a language is any specific example of such a system. Not only it is used to communicate but also to establish and maintain social relationships. It is an essential symbol of ethnic, social and cultural identities as well as determined be as a mirror of a society and a nation. According to Verdoodt (1997) and Llamas, Mullany, and Stockwell (2006), beyond its symbolic role as a communication tool, it is also considered as the most significant factor in maintaining and continuing ethnic identities across ethnic groups and generations. Language, in addition; it is a key factor of intergenerational transmission in order to understand the values, history, and philosophy of human life from generation to generation.
Speaking is the language skill that is used to express ideas and thoughts through communication with the others so that to know information. Secondly, in conveying the information, sharing the knowledge and expressing the feelings are not as easy as we think. It needs some language competencies and proficiencies among others should be mastered, such as the grammatical rules (syntax), the morphology, semantics as well as fluency and accuracy. In teaching and learning process, the teacher always apply many kinds of method in the classroom including in teaching English language to reach the target curriculum in every semester. In learning English is not easy to the students to get target language because there are some of language aspect that must be mastered. There are pronunciation, vocabulary, grammar, etc.

Therefore, the teacher can apply many kinds of technique or methods in teaching process so that the students can master the skills of English namely: 
listening, speaking, reading, and writing. Speaking is one of the skills that must be mastered by the learners in learning a language including in learning English. Speaking is one of the ability to speak and communicate in communicating process. He also says that speaking is one of the first things that are very important, no language exists without speaking. While Campbell (1978:32) says that speaking is an activity on the part of that other to understand what was in the mind of the first. Furthermore, speaking is also an interaction process between a speaker and a listener, in speaking there is a process of communication which conveys the messages from a speaker to listener orally. It means that in orally communication. In language teaching a teacher of a foreign language needs a special selection of communicative approaches, methods and techniques that can be used in the classroom to present the materials. Sometimes, when organizing and planning speaking instruction, most of the teachers use a combination of instructional approaches and methods.

Setiyadi (2006:15) points out that "language teachers may develop their own technique are still consistent with the assumptions or theories of the methods from which the technique derive". A creative teacher might use a new method that has acquired successfully she or he might try to modify a method by combining different techniques relevant to the purpose and material given. As we know that many of the students are not interested in learning speaking. It is happened because of some reasons, such as less confidence or shy, silent preference, use their own language, and etc. to solve these problems, the teachers need many kind of methods or techniques and approach in the activities in process of teaching and learning.

The Direct Method is allows students to perceive meaning directly through the target language because no translation is allowed. Visual aids and pantomime are used to clarify the meaning of vocabulary items and concept. Student speak a great deal in the target language and communicative as if in real situation. The Direct Method, which is also known as natural method or conversational method, has been popular since it enables students to communicate in the foreign language. The Direct Method through focusing on everyday language, and using questions and answers lays an emphasis on teaching oral language. In this case, the writer wants to conduct a research about "The effect of using direct method in teaching speaking skill ".

The Direct method will enable learners to engage in speaking of good works for enjoyment and for selfdevelopments. They will also develop an understanding of other societies, cultures, values and traditions that will contribute to their emotional and spiritual growth. The Direct Method is one of technique that can be used by the teacher to increase students' achievement in speaking English. The primary objective of this method is associate meaning and the target language directly through the use of regalia, pictures or pantomime (LarsenFreeman, 1986, p.29). Rivers summarizes the characteristics of the Direct Method as "students learn to understand a language by listening to a great deal of it and that they learn to speak it by speaking it- associating speech with appropriate action" (Rivers, 1968, s.18).

Richard and Rodgers (1986:910) the basic premise of the direct method was that second language 
learning should be more like first language learning: lots of active oral interaction, spontaneous uses often language, no translation between first and second language, and little or no analysis of grammatical rules. Richard and Rodgers (1986:9-10) also summarize that there are some principles of the direct method, that must be understand by the English teacher. There are as follow:

a. Classroom instruction was conducted exclusively in the target language

b. Only everyday vocabulary and sentences were taught.

c. Oral communication skills were built up in a carefully graded progression organized around question and answer exchange between teachers and students in small, intensive classes.

d. Grammar was taught inductively.

e. New teaching points were introduced orally.

f. Concrete vocabulary was taught through demonstration, objects and picture, abstract vocabulary was taught by association of ideas.

g. Both speech and listening comprehension were taught.

h. Correct pronunciation and grammar were emphasized.

The direct method enjoyed considerable popularity through the end of the nineteenth century and well into this one. It was most widely accepted in private language school where students were highly motivated and where native-speaking teachers could be employed. Based on discussion and background above,

\subsection{Research Question}

Based on the explanations above, the issue to be studied was formulated into the following research questions:
1) How is students' speaking skill before being taught by using Direct Method?

2) How is students' speaking skill after being taught by using Direct Method?

3) Is there any significant difference of students' speaking skill before and after being taught by using Direct Method at the second year of SMK Negeri 1 Bener MeriahAceh?

\subsection{The Significance of the Topic}

This study is very important because it will give some contributions or motivation in teaching speaking skill and carry out for the following benefits

- To provide some information to the teacher about techniques and methods to improve students' speaking skill.

- To attract students' participation that study English is enjoyable.

- To expected to be able to enhance proficiency in teaching speaking skill through direct method.

- The Teachers who use the Direct Method believe students need to associate meaning with the target language directly. In order to do this, when the teacher introduces a new target language word or phrase, he demonstrates its meaning through the use of regalia, pictures, or pantomime; he never translates it into the students' native language. Teachers who use the Direct Method intend that students learn how to communicate in the target language.

- The Teacher can compare the finding teaching speaking by using direct method without using another method. 


\section{LITERATURE REVIEW}

2.1. The Theoretical Framework

2.1.1. Teaching English by Using Direct Method

According to Lie (2002:55)

there are some of methods in teaching English foreign language can be used in teaching process. Among them are:

- Grammar Translation Method (GTM)

- Direct Method

- Audio Language Method

- Silent Way

- The Scientific Approach

- $\quad$ Suggestopedia

- Community Language Learning (CLL)

- Total physical Response (TPR)

- Communicative Approaches/Communicative Language Teaching(CLT)

- Community Teaching Language (CTL)

- $\quad$ Purpose Based Language (PBL)

- Etc.

Technique is the different methods that make use of different kind of classroom activity. There are some techniques in teaching English as foreign language in teaching English at the classroom:

- Role play/ simulation

- Story telling

- Game

- Interview

- Map drawing

- Dictation

- Zig saw

- Drill

- Dialogue

- Fill-in-the-blank

Approach for foreign language teaching and learning is a set of correlative assumptions dealing with the nature of language teaching and learning. An approach is axiomatic. It describes the nature of the subject matter to be taught. An Approach could be seen as your perspective, ideology, belief or theoretical stance on something.

There are some approaches in teaching English:

a. Natural approach

b. Scientific approach

c. Oral approach

d. Structural approach

e. Communicative approach

f. Cognitive-code approach

g. Aural-oral approach

\section{RESEARCH METHOD}

The type of the research is experimental research. According Jhon, W. Cresswell, (2008, p. 299) says that "Experiment is you test an idea (or practice procedure) to determine whether it influences an outcome or dependent variable". The research design is pre-experimental research. In this research, the writer uses the design of the pre -test post-test in one group. Because in conducting this research, one class of second year students of SMK Negeri 1 Bener Meriah-Aceh has been participate. The class got a pre-test at the beginning, treatment in the middle and post-test at the end of the research. The pre-test and post-test results have been being compared in order to determine the effect of the treatment. Gay (2000, p. 388) says that, this research called the One-Group Pretest-Post-test Design, involves a single group that is pre-tested, exposed to a treatment, and post-tested. The success of the treatment was determined by comparing pre-test and post-test scores.

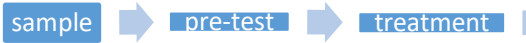

Figure. 3.1. Diagram Research Design 


\subsection{Research Location}

This research conducted to the second grades students of SMK Negeri 1 Bener Meriah-regency of Bener Meriah-Aceh, Indonesia

\subsection{Research Subject and Object}

\subsubsection{The Subject of the Research}

The subject of the research the students of second year of SMK Negeri 1 Bener Meriah Regency of Bener Meriah- Aceh, Indonesia.

\subsubsection{The Object of the Research}

The object of the research the effect of using the direct method in increasing students' speaking skill.

\subsection{The Population and the Sample of} the Research

The population of this research the second year students of SMK Negeri 1 Bener Meriah which consisted of six classes. There were 20, 25 and 30 students in each class, so the total of the population was approximately 135 students.

Table 3.1. The number of the second year students of smk negeri 1 bener meriah-aceh

\begin{tabular}{ccccc}
\hline & & \multicolumn{3}{c}{ Population } \\
\cline { 3 - 5 } No & Class & Male & Female & Total \\
1 & XI TKJ & 18 & 12 & 30 \\
2 & XI TIL & 10 & 15 & 25 \\
3 & XI TKK & 15 & 10 & 25 \\
4 & XTKR & 28 & 2 & 30 \\
5 & XI TSM & 30 & 0 & 30 \\
6 & XIwelding & 25 & 0 & 25 \\
$\quad$ Total & & & 135 \\
\hline
\end{tabular}

The research design One-Group

Pretest-Post design, so the researcher chooses one class as sample. This technique was called Cluster Sampling because the students' ability in speaking English homogenous and the students are at the same level, taught with the similar material and teachers. The sample in this research was the class XI TKJ where the total of the students were
30 students, consist of 18 students of male and 12 students of female.

\subsection{The Technique of Collecting Data}

To measure students' ability in speaking, the researcher used oral test. Oral test was given twice, they were:

a. Pre-Test

Pre-Test used to collect the data of students before applying direct method

b. Post-Test

Pre-Test used to collect the data of students after applying direct method.

After giving pretest, the researcher applied the treatment. Here the blueprint of the treatment

Table 3.2. The blueprint of treatment

\begin{tabular}{|c|c|}
\hline Meetings & Subject Method \\
\hline Meeting 1 & $\begin{array}{llr}\text { 1. } & \text { Responding } & \text { and } \\
\text { understanding } & \text { tex } \\
\text { monologue of recoun } \\
\text { text }\end{array}$ \\
\hline Meeting 2 & $\begin{array}{l}\text { 1. Responding to } \\
\text { introducing, meeting, and } \\
\text { leaving the conversation } \\
\text { 2. Doing various } \\
\text { transactional/ } \\
\text { interpersonal } \\
\text { conversations in order to } \\
\text { introduce, meet, and } \\
\text { leave the conversation }\end{array}$ \\
\hline Meeting 3 & $\begin{array}{l}\text { 1. Responding to } \\
\text { expressing happiness } \\
\text { 2. Doing various use of } \\
\text { language orally in } \\
\text { transactional/interperson } \\
\text { al in order to expressing } \\
\text { happiness }\end{array}$ \\
\hline Meeting 4 & 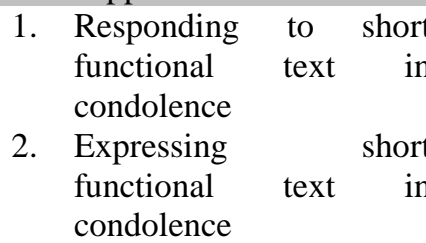 \\
\hline Meeting 5 & $\begin{array}{l}\text { 1. Responding the meaning } \\
\text { in the simple monologue } \\
\text { text of recount text } \\
\text { 2. Expressing the meaning } \\
\text { in the simple monologue } \\
\text { text of recount text }\end{array}$ \\
\hline Meeting 6 & $\begin{array}{l}\text { 1. Expressing to shor } \\
\text { functional text orally } \\
\text { 2. Retelling about shor }\end{array}$ \\
\hline
\end{tabular}




\begin{tabular}{lrl}
\hline Meeting 7 & 1. & $\begin{array}{l}\text { functional text } \\
\text { Responding and } \\
\text { analyzing the short story } \\
\text { Retelling unforgettable } \\
\text { memory }\end{array}$ \\
Meeting 8 & 1. $\begin{array}{l}\text { Expressing the meaning } \\
\text { in the simple monologue } \\
\text { text which uses various } \\
\text { oral languages } \\
\text { accurately, fluently, and } \\
\text { contextually. }\end{array}$ \\
\hline
\end{tabular}

\subsection{The Technique of Data Analysis}

The researcher scored the students' speaking ability according to categories developed by Hughes. He says that there are some components that should be considered to score speaking skill. They are accent, grammar, vocabulary, fluency, and comprehension. The speaking ability was scored by counting five qualities above and each component has score or level. Each component has the highest score 20 and the highest of teacher' score is 100 . The specification of the test is as follow:

Table 3.3. Assessment aspects of speaking ability on recount text

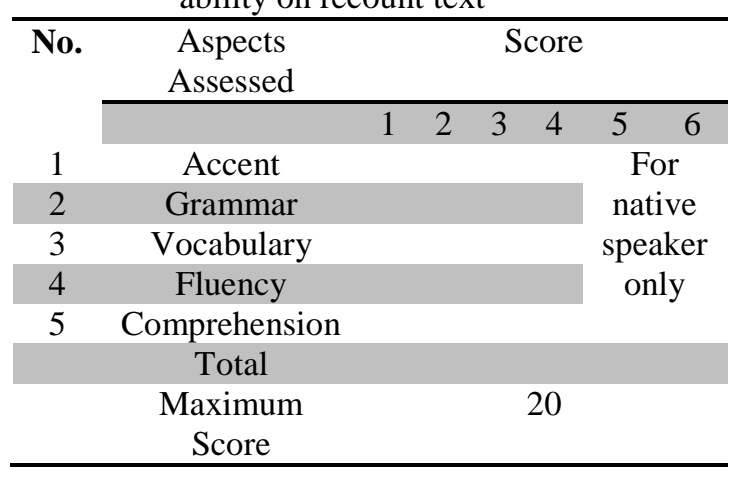

Explanation of score:

$1=$ incompetent

$2=$ competent enough

$3=$ competent

$4=$ very competent

Final score $=$ total score: maximum score $\mathrm{x} 100$

So, based on the table above, the classification of the students' speaking ability can be rated as follows
Table 3.4. Classification of the students' score in term of the level of ability

\begin{tabular}{cc}
\hline Score & Classification \\
\hline $\mathbf{8 0 - 1 0 0}$ & Excellent \\
$\mathbf{6 6 - 7 9}$ & Good \\
$\mathbf{5 6 - 6 5}$ & Average \\
$\mathbf{4 0 - 5 5}$ & Poor \\
$\mathbf{0 - 3 9}$ & Failed \\
\hline
\end{tabular}

Then, the students' score will be analyzed by using statistical analysis, to know if there is any significant effect of using direct method on the students speaking ability. Thus, the different mean is analyzed by using T-Test through SPSS 16 version.

The $\mathrm{t}$ - table was employed to see whether there is a significant effect on using direct method on the students' speaking ability.

The $\mathrm{F}$ calculated is obtained by considering variable of $\mathrm{dk}$ as follows:

$\mathrm{dk}=\mathrm{N}$ - independent variable -1

$\mathrm{N}=$ Number of cases

The significant level chosen in analyzing the score $\mathrm{F}$ calculated through using SPSS 16 Version is $5 \%$ or 0.05. Statistically the hypotheses are:

Ha : to > ttable

Ho : to $<$ ttable

$\mathrm{Ha}$ is accepted if tobtained $>$ ttable or there is effect of using direct method on the students' speaking ability.

Ho is accepted if tobtained < ttable or there is no effect of using direct method on the students' speaking ability.

\section{RESULTS AND DISCUSSION}

The results revealed that teachers who use the Direct Method Intend that students learn how to communicate in the target language. In order to do this successfully, students should learn to think in the target language. It is to find the increasing of the students' achievement in Speaking English through Direct Method. Direct Method is an interesting method that 
can used by the teacher to improving students speaking skill.

This study shows an interesting finding, The Direct Method has one very basic rule: No translation is allowed. In fact, the Direct Method receives its name from the fact that meaning is to be conveyed directly in the target language through the use of demonstration and visual aids, with no recourse to the students' native language. The Direct Method believe students need to associate meaning with the target language directly. In order to do this, when the teacher introduces a new target language word or phrase, he demonstrates its meaning through the use of regalia, pictures, or pantomime; he never translates it into the students' native language. Students speak in the target language a great deal and communicate as if they were in real situations. In fact, the syllabus used in the Direct Method is based upon situations (for example, one unit would consist of language that people would use at a bank, another of the language that they use when going shopping) or topics (such as geography, money, or the weather). Grammar is taught inductively; that is, the students are presented with examples and they figure out the rule or generalization from the examples. An explicit grammar rule may never be given.

\section{CONCLUSIONS}

Based on the findings explained research on the effect of using direct method in teaching speaking skill at the second year of SMK Negeri 1 Bener Meriah-Aceh have completely discussed. It is necessary for the researcher to draft the conclusions as follows:

1. The students' ability in speaking before being taught by using direct method. After conducting the research, the students' speaking ability before being taught by using direct method is categorized into Poor level.

2. The students' speaking ability after being taught by using direct method. After conducting the research, the students' speaking ability before being taught by using direct method is categorized into Good level.

3. It shows that there is significant difference on students speaking ability before and after being taught by using direct method at the the second year of SMK Negeri 1 Bener Meriah-Aceh.

\section{REFERENCES}

Anas Sudijono. 2000. Pengantar Statistik Pendidikan. Jakarta: PT Grafindo Persada.

Brown, H. Douglas. 2000. Teaching by Principles: an Interactive Approach to Language Pedagogy $2^{\text {nd }}$ Edition. San Francisco, California: Longman.

Cresswell, Jhon W. 2008. Educational Research: Planning, Conducting, and Evaluating Quantitative and Qualitative Research. New Jersey: Person Education Inc.

Hughes, Arthur. 1989. Testing for Language Teachers. United Kingdom: Cambridge University.

Llamas, C., Mullany, L., \& Stockwell, P. 2006. The Routledge companion to sociolinguistics. London: Routledge

Larsen-Freeman,D. 2000. Techniques and Principles in Language Teaching. Oxford: Oxford University Press.

Larsen-freeman, Diane. 1986. Technique and Principle in Language Teaching. England: Oxford University Press Inc.

L. R, Gay and Peter Airasian. 2000. Educational Research. New Jersey: Pearson Education Ltd. 
Larsen, Cullan. 2000. Techniques and principles in Language Teaching. London: Oxford University Press.

Richards, J. \& Rodgers T. (2007). Approaches and Methods in Language Teaching. Cambridge University Press.

Rivers, W.M. (1968). Teaching Foreign Language Skills. University of Chicago Press
Setiyadi. 2006. Using Close Exercise to Improve Speaking Comprehension. Unpublished: Syiah Kuala University

Verdoodt, A. F. (1997). The demography of language. In $\mathrm{F}$. Coulmas (Ed.), The handbook of sociolinguistics (pp. 33-43). Oxford: Blackwell 